\title{
PENGARUH KECERDASAN EMOSIONAL, KOMPETENSI, DAN MOTIVASI TERHADAP KINERJA PEGAWAI SETDA KABUPATEN WONOGIRI
}

\author{
Tulus Wahyu Kuncoro, Sudarwati, Djumali \\ Fakultas Ekonomi Universitas Batik Surakarta \\ Email : tuluswahyu191@gmail.com
}

\begin{abstract}
Abstrak: Penelitian bertujuan untuk mengetahui: 1) pengaruh secara parsial antara kecerdasan emosional dan kompetensi, serta motivasi terhadap kinerja pcgawai Setda Kab. Wonogiri. 2) Pengaruh secara simultan antara kecerdasan emosional dan kompetensi, serta motivasi terhadap kinerja Pegawai Setda Kabupaten Wonogiri. Penelitian ini adalah penelitian kuantitatif dengan populasi penelitian seluruh pegaswai Setda Kab Wonogiri berjumlah 150 pegawai. Sampel penelitian berjumlah 75 responden. Dengan metode probability sampling, dengan teknik simple random sampling. Teknik pengumpulan data menggunakan adalah observasi, angket/kuesioner dan dokumentasi. Teknik analisis data menggunakan analisis regresi linier berganda, dilanjutkan uji f, uji $t$, dan koefisien determinasi. Hasil penelitian menunjukkan: l) dari hasil uji $t$ dapat diperoleh variabel kecerdasan emosional dengan nilai thitung = 2,144 > ttabel 1,66, maka Ho ditolak sehingga ada pengaruh signifikan kecerdasan emosional terhadap kinerja pegawai Setda Kab. Wonogiri, variabel kompetensi nilai thitung $=$ $2.757>$ ttabel $=1,66$, maka Ho ditolak sehingga ada pengaruh yang signifikan kompetensi terhadap kinerja pegawai Setda Kab. Wonogiri, variabel motivasi diperoleh nilai thitung = 5,134 > ttabel = 1,66, maka Ho ditolak sehingga ada pengaruh yang signifikan motivasi terhadap kinerja pegawai Setda Kab. Wonogiri. 2) Hasil perhitungan uji F diperoleh diperoleh nilai Fhitung $=23,7013>$ Ftabel $=2,73$, maka Ho ditolak sehingga secara simultan ada pengaruh yang signifikan kecerdasan emosional (X1), kompetensi $\left(X_{2}\right)$, motivasi $\left(X_{3}\right)$ terhadap kinerja pegawai (Y). 3) Hasil perhitungan koefisien determinasi diperoleh, $R^{2}=0,500$, ini dapat diartikan bahwa $50 \%$ perubahan atau variasi $Y$ (kinerja pegawai) dikarenakan adanya perubahan atau variasi variabel $X$ (kecerdasan emosional, kompetensi, motivasi). Sedangkan $50 \%$ sisanya dikarenakan adanya perubahan variabel lain yang tidak masuk dalam model misalnya pengalaman kerja, insentif, promosi jabatan dan sebagainya.
\end{abstract}

Kata kunci: kecerdasan emosional, kompetensi, motivasi, kinerja pegawai

\section{PENDAHALUAN}

Peningkatan kualitas sumber daya manusia dapat dilakukan dengan melakukan pengelolaan dan pelatihan yang rutin dan baik, mencari dan meningkatkan faktor-faktor apa saja yang dapat mempengaruhi kualitas dan kinerja sumber daya manusia. Sumber daya manusia memiliki peranan yang sangat penting bagi suatu perusahaan atau organisasi sebagai pengelola sistem, agar sistem dalam perusahaan atau organisasi berjalan lancar, tentu dalam pengelolaannya harus memperhatikan aspek-aspek penting seperti motivasi, kompetensi, disiplin dan latihan serta tingkat kenyamanan lingkungan bekerja sehingga pegawai dapat terdorong untuk memberikan segala kemampuan sesuai dengan yang dibutuhkan oleh organisasi.

Dengan SDM yang baik, maka akan menciptakan kinerja pegawai yang baik pula. Sehingga segala tujuan organisasi atau perusahaan dapat diraih dengan maksimal. Menurut 
Wirawan (2009) kinerja adalah keluaran yang dihasilkan oleh fungsi-fungsi atau indikatorindikator suatu pekerjaan atau suatu profesi dalam waktu tertentu. Aspek-aspek kinerja pegawai yang akan dikaji dalam penelitian ini meliputi kecerdasan emosional, kompetensi dan motivasi.

Lokasi penelitian yaitu Kantor Setda Kabupaten Wonogiri yang beralamat di Jalan Kabupaten Wonogiri No. 6 Wonogiri. Pada observasi awal peneliti menemukan beberapa pegawai yang memiliki kinerja cenderung rendah. Hal tersebut dapat dipengaruhi oleh beberapa faktor seperti faktor internal dan eksternal pegawai tersebut. Maka perlu mendapat perhatian yang lebih dari perusahaan.

Sehubungan dengan hal tersebul timbul pemikiran bagaimana keseluruhan aspek (kecerdasan emosional, kompetensi dan motivasi) saling berkeseimbangan sehingga mempengaruhi kinerja pcgawai, untuk itu diperlukan penelitian yang dapat membuktikan bahwa faktor-faktor tersebut mempunyai pengaruh terhadap kinerja pegawai.

\section{LANDASAN TEORI}

\section{Kinerja Pegawai}

Wirawan (200) menyatakan kinerja adalah keluaran yang dihasilkan oleh fungsi-fungsi atau indikator-indikator suatu pekerjaan atau suatu profesi dalam waktu tertentu. Sementara Setiawan dan Kartika (2014) untuk mengukur kinerja dapat menggunakan indikator sebagai berikut :

a. Ketepatan penyelesaian tugas merupakan pengelolaan waktu dalam bekerja dan juga ketepatan karyawan dalam menyelesaikan pekerjaan.

b. Kesesuaian jam kerja merupakan kesediaan karyawan dalam mematuhi peraturan perusahaan yang berkaitan dengan ketepatan waktu masuk/pulang kerja dan jumlah kehadiran.

c. Jumlah ketidakhadiran karyawan dalam suatu perusahaan selama periode tertentu.

d. Kerjasama antar karyawan merupakan kemampuan karyawan untuk bekerja sama dengan orang lain dalam menyelesaikan suatu tugas yang ditentukan sehingga mencapai daya guna dan hasil guna yang sebesar-besarnya.

\section{Kecerdasan Emosional}

Kecerdasan emosional adalah kemampuan seperti kemampuan untuk memotivasi diri sendiri dan bertahan menghadapi frustasi, mengendalikan dorongan hati dan dan tidak melebih lebihkan kesengangan, mengatur suasana hati dan menjaga agar beban stres tidak melumpuhkan kemampuan berfikir, berempati dan berdo'a. (Goleman D, 2015).

Aspek-aspek kecerdasan emosional (Gardner, 2003):

a. Mengenali Emosi Diri

b. Mengelola Emosi

c. Memotivasi Diri Sendiri

d. Mengenali Emosi Orang lain (Empati)

e. Membina Hubungan

\section{Kompetensi}

Kompetensi berasal dari kata Bahasa Inggris yaitu competent yang dalam Bahasa Indonesia memiliki arti cakap, mampu atau tangkas. Competency secara umum diartikan sebagai kecakapan, kemampuan, dan kewenangan. Untari (2014) menyatakan bahwa kompetensi adalah keahlian dan ketrampilan dasar serta pengalaman seseorang, staf atau pimpinan yang dapat mempengaruhi dalam melaksanakan pekerjaan atau tugas lain secara efektif dan efisien atau sesuai standar instansi yang telah ditentukan.

Menurut Zwell (2000) kompetensi seseorang dapat dipengaruhioleh beberapa faktor antara 
lain:
a. Keyakinan dan nilai-nilai
b. Karakteristik kepribadian
c. Motivasi
d. Isu emosional
e. Kemampuan intelektual
f. Budaya organisasi

\section{Motivasi}

Menurut Robbins (2013) definisi dari motivasi yaitu kesedian untuk mengeluarkan tingakat upaya yang tinggi untuk tujuan organisasi yang dikondisikan oleh kemampuan upaya itu untuk memenuhi beberapa kebutuhan individual. Motivasi diartikan sebagai kekuatan (energi) seseorang yang dapat menimbulkan tingkat persistensi dan entusiasmenya dalam melaksanakan suatu kegiatan, baik yang bersumber dari dalam diri individu itu sendiri (motivasi intrinsik) maupun dari luar individu (motivasi ekstrensik). Motivasi merupakan akibat dari intraksi seseorang dengan situasi tertentu yang dihadapi. Indikator motivasi kerja menurut Sunyoto (2013):
a. Promosi
b. Prestasi kerja atau keberhasilan dalam bekerja
c. Pekerjaan itu sendiri
d. Penghargaan/ Pengakuan
e. Tanggung jawab

\section{Kerangka Berpikir}

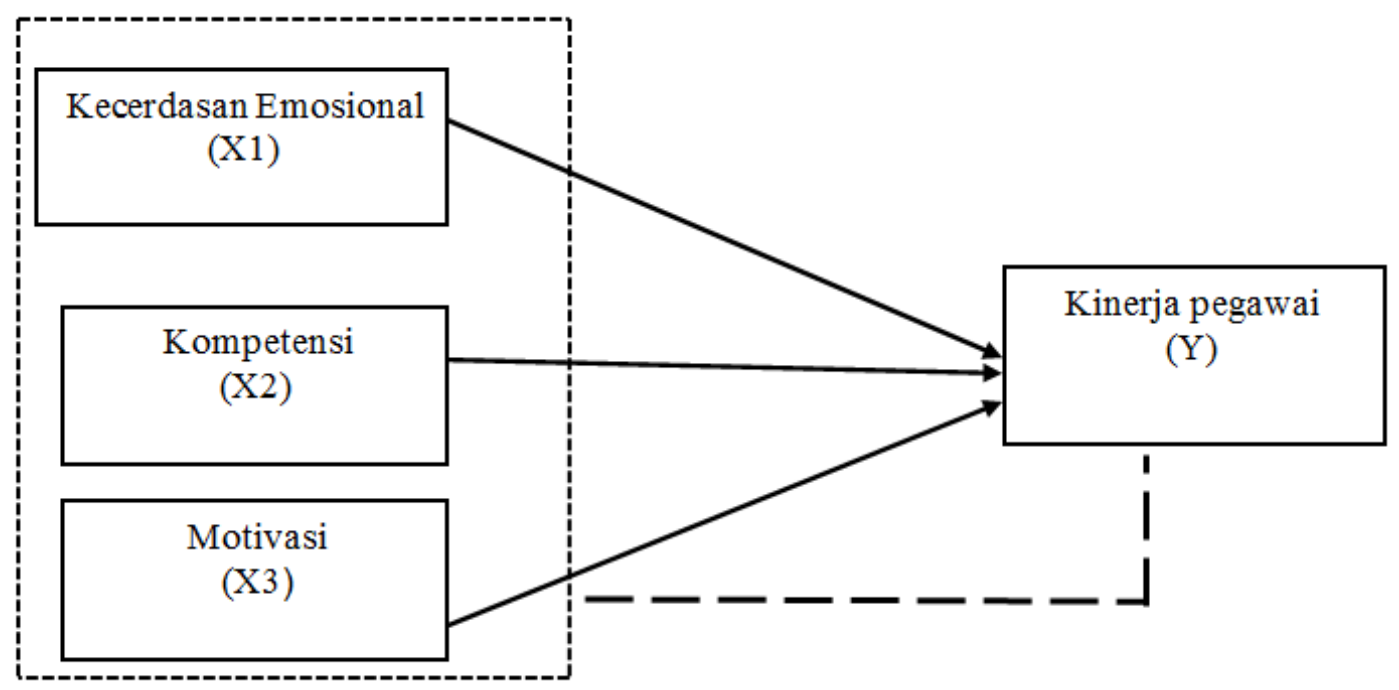

\section{Hipotesis}

1) Diduga kecerdasan emosional, kompetensi, dan motivasi pegawai berpengaruh secara simultan terhadap Kinerja Pegawai Setda Kabupaten Wonogiri.

2) Diduga kecerdasan emosional pegawai berpengaruh positif dan signifikan terhadap Kinerja Pegawai Setda Kabupaten Wonogiri. 
3) Diduga kompetensi pegawai berpengaruh positif dan signifikan terhadap Kinerja Pegawai Setda Kabupaten Wonogiri.

4) Diduga motivasi pegawai berpengaruh positif dan signifikan terhadap Kinerja Pegawai Setda Kabupaten Wonogiri.

\section{METODE PENELITIAN}

Metode yang digunakan adalah kuantitatif, dengan pendekatan deskriftif, sedangkan teknik sampling penelitian ini adalah problability sampling dengan teknik simple random sampling. Sampel sejumlah 75 responden pegawai Setda Kabupaten Wonogiri. Teknik analisa data pada penelitian ini adalah uji asumsi klasik, uji hipotesis.

\section{HASIL DAN PEMBAHASAN}

Uji Asumsi Klasik

1) Uji Normalitas

Tabel 1

Hasil Pengujian Normalitas

\begin{tabular}{|c|c|c|c|}
\hline Variabel & $\begin{array}{c}\text { Asymp Sign } \\
(2-\text { tailed P) }\end{array}$ & Keterangan & Distribusi \\
\hline Unstandardized-Residual & 0,978 & $\mathrm{P}>0,05$ & Normal \\
\hline
\end{tabular}

Dari tabel diatas dapat diketahui bahwa seluruh variabel berdistribusi normal, sehingga pengujian dapat dilanjutkan.

2) Uji Multikolinearitas

Tabel 2

Hasil Pengujian Multikolinieritas

\begin{tabular}{|c|l|c|c|c|c|}
\hline No & \multicolumn{1}{|c|}{ Variabel } & $\begin{array}{c}\text { Tole } \\
\text { rance }\end{array}$ & VIF & A & Keterangan \\
\hline 1 & Kecerdasan Emosional & 0,715 & 1,399 & 10 & Bebas multikolinieritas \\
\hline 2 & Kompetensi & 0,682 & 1,466 & 10 & Bebas multikolinieritas \\
\hline 3 & Motivasi & 0,914 & 1,094 & 10 & Bebas multikolinieritas \\
\hline
\end{tabular}

Dari tabel di atas dapat diketahui bahwa nilai Tolerance $>0,10$ atau nilai VIF $<10$, sehingga tidak terjadi multikolinieritas. 
3) Uji Heterokedastisitas

Tabel 3

Hasil Uji Heteroskedastisitas

\begin{tabular}{|l|c|c|c|}
\hline \multicolumn{1}{|c|}{ Variabel } & Sig. & $\begin{array}{c}\text { Taraf } \\
\text { Signifikansi } \\
(\square)\end{array}$ & Kesimpulan \\
\hline Kecerdasan emosional & 0,726 & 0,05 & Bebas heteroskedastisitas \\
\hline Kompetensi & 0,938 & 0,05 & Bebas heteroskedastisitas \\
\hline Motivasi & 0,399 & 0,05 & Bebas heteroskedastisitas \\
\hline
\end{tabular}

Dari tabel di atas dapat diketahui bahwa Sig. > Taraf Signifikansi, sehingga H0 diterima dan tidak terjadi heteroskedasitas.

\section{Uji Hipotesis}

1) Uji Linier Berganda

Rumus yang digunakan adalah sebagai berikut :

$\mathrm{Y}=\mathrm{a}+b_{1}{ }_{1}+b_{2} X_{2}+\mathrm{b} 2 \mathrm{X} 3+\mathrm{e}((\operatorname{Ghozali}(2009: 17))$

Dari hasil tersebut, maka persamaan regresinya sebagai berikut :

$\mathrm{Y}=0,75+0,375 \mathrm{X} 1+0,300 \mathrm{X} 2+0,539 \mathrm{X} 3$

Dari persamaan regresi linier berganda diatas memberikan keterangan sebagai berikut:

a. Konstanta $\mathrm{a}=0,75$

Ini menunjukkan bahwa kecerdasan emosional, kompetensi dan motivasi kerja mempunyai pengaruh terhadap kinerja pegawai.

b. Koefisien b1 $=0,375$

Ini menunjukkan pengaruh positif yaitu apabila kecerdasan emosional yang dimiliki semakin meningkat maka mengakibatkan kinerja pegawai meningkat.

c. Koefisien b2 $=0,300$

Ini menunjukkan pengaruh positif yaitu apabila kompetensi yang diberi kan semakin meningkat maka mengakibatkan kinerja pegawai meningkat.

d. Koefisien b3 =0,539

Ini menunjukkan pengaruh positif yaitu apabila motivasi yang diberikan semakin meningkat maka mengakibatkan kinerja pegawai meningkat.

2) Uji regresi simultan (uji F)

Uji $\mathrm{F}$ digunakan untuk menguji koefisien regresi secara simultan atau bersama-sama antara variabel dependen. Berdasarkan hasil analisis uji F diperoleh Fhitung = 23,703 dengan Ftabel $=2,73$, jadi Fhitung $>$ Ftabel sehingga Ho ditolak dengan kata lain terdapat pengaruh yang signifikan secara bersama- sama antara variabel kecerdasan emosional (X1), kompetensi (X2), dan motivasi $(\mathrm{X} 3)$ terhadap kinerja pegawai $(\mathrm{Y})$. 
3) Uji regresi parsial (ujit)

a. Uji t yang berkaitan dengan kecerdasan emosional (X1) terhadap kinerja pegawai (Y) Dari perhitungan tersebut diperoleh hasil thitung $=2,144>$ ttabel $=1,66$ maka Ho ditolak sehingga ada pengaruh yang signifikan kecerdasan emosional terhadap kinerja pegawai.

b. Uji t yang berkaitan dengan kompetensi (X2) terhadap kinerja pegawai (Y)

Dari perhitungan tersebut diperoleh hasil thitung $=2,757>$ tabel $=1,66$ maka Ho ditolak sehingga ada pengaruh yang signifikan kompetensi terhadap kinerja pegawai

c. Uji t yang berkaitan denganmotivasi (X3) terhadap kinerja pegawai (Y) Dari perhitungan tersebut diperoleh hasil thitung $=5,134>$ tabel $=1,66$ maka Ho ditolak sehingga ada pengaruh yang signifikan motivasi terhadap kinerja pegawai

\section{Uji Determinasi $\left(\mathbf{R}^{2}\right)$}

Dari hasil uji koefisien determinasi diperoleh $\mathrm{R}^{2}=0,500$ ini dapat diartikan bahwa 52,1\% perubahan atau variasi Y (kinerja pegawai) dikarenakan oleh adanya perubahan atau variasi variabel X (kecerdasan emosional, kompetensi, motivasi). Sedangkan 47,9\% sisanya dikarenakan oleh adanya perubahan variabel lain yang tidak masuk dalam model misalnya pengalaman kerja, insentif, promosi jabatan dan sebagainya.

\section{Pembahasan}

Berdasarkan hasil analisis diatas, maka pembahasan adalah sebagai berikut:

1) Berdasarkan hipotesis yang disampaikan "Diduga variabel kecerdasan emosional, kompetensi, dan motivasi berpengaruh secara signifikan terhadap variabel kinerja pegawai" terbukti, ditunjukkan dengan hasil analisis regresi linier berganda sebagai berikut $: \mathrm{Y}=0,75+0,375 \mathrm{X} 1+0,300 \mathrm{X} 2+0,539 \mathrm{X} 3$.

2) Sedangkan dari hasil uji t dapat diperoleh variabel kecerdasan emosional dengan nilai thitung $=2,144>$ ttabel $=1,66$, maka Ho ditolak sehingga ada pengaruh yang signifikan kecerdasan emosional terhadap kinerja pegawai. Hasil tersebut sesuai dengan kesenjangan penelitian dalam latar belakang, apabila kecerdasan emosional yang dimiliki tergolong baik, maka akan mendorong pegawai dalam meningkatkan kinerja mereka.

3) Dari hasil uji $\mathrm{t}$ dapat diperoleh variabel kompetensi dengan nilai thitung $=2,757>$ ttabel $=$ 1,66, maka Ho ditolak sehingga ada pengaruh yang signifikan kompetensi terhadap kinerja pegawai. Hasil tersebut sesuai dengan kesenjangan penelitian dalam latar belakang, apabila kompetensi yang dimiliki pegawai tergolong baik, maka akan mendorong pegawai dalam meningkatkan kinerja mereka.

4) Dari hasil uji $\mathrm{t}$ dapat diperoleh variabel motivasi dengan nilai thitung $=5,134>$ ttabel $=$ 1,66, maka Ho ditolak sehingga ada pengaruh yang signifikan motivasi terhadap kinerja pegawai. Hasil tersebut sesuai dengan kesenjangan penelitian dalam latar belakang, apabila motivasi yang dimiliki pegawai tergolong baik, maka akan mendorong pegawai dalam meningkatkan kinerja mereka.

5) Begitu juga dari hasil perhitungan uji F dapat diperoleh diperoleh nilai Fhitung = 23,703 > Ftabel $=2,73$, maka Ho ditolak sehingga secara bersama-sama ada pengaruh yang signifikan kecerdasan emosional (X1), kompetensi (X2), motivasi (X3) terhadap kinerja pegawai (Y). 


\section{KESIMPULAN}

1) Hasil uji F menunjukkan kecerdasan emosional, kompetensi, dan motivasi berpengaruh secara simultan terhadap kinerja pegawai di Setda Kabupaten Wonogiri.

2) Hasil uji t menunjukkan:

a. Ada pengaruh positif dan signifikan kecerdasan emosional terhadap kinerja pegawai di Setda Kab. Wonogiri.

b. Ada pengaruh positif dan signifikan kompetensi terhadap kinerja pegawai di Setda Kab. Wonogiri.

c. Ada pengaruh positif dan signifikan motivasi terhadap kinerja pegawai di Setda Kab. Wonogiri.

3) Hasil analisis linier berganda sebagai berikut:

$\mathrm{Y}=0,75+0,375 \mathrm{X} 1+0,300 \mathrm{X} 2+0,539 \mathrm{X} 3$. Dari persamaan ini menunjukkan bahwa variabel kecerdasan emosional, kompetensi, dan motivasi berpengaruh signifikan terhadap variabel kinerja pegawai.

\section{Saran}

1) Sebaiknya faktor-faktor tersebut diperhatikan atau perlu ditingkatkan lagi oleh manajemen Setda Kab. Wonogiri, karena hasil analisis data menunjukkan adanya pengaruh yang signifikan antara kecerdasan emosional, kompetensi, dan motivasi terhadap kinerja pegawai.

2) Manajemen Setda Kab. Wonogiri dalam usaha meningkatkan kinerja pegawai, maka pemerintah seyogyanya memperhatikan komunikasi antar pegawai yang selaras.

\section{DAFTAR PUSTAKA}

Arikunto, Suharsimi. 2002. Prosedur Penelitian Suatu Pendekatan Praktek. Cet.I. Jakarta: Rineka Cipta. 2010. Prosedur Penelitian. Jakarta: Rineka Cipta.

As'ad, Moh. 2001. Seri Ilmu SDM: Psikologi Industri. Edisi Keempat. Yogyakarta: Liberty.

Bangun, Wilson. 2012. Manajemen Sumber Daya Manusia. Bandung: Erlangga. Goleman, Daniel. Emotional Intelligence terjemahan T. Hermaya. Jakarta: Gramedia Pustaka Utama, 2015.

Gardner, Howard. 2003. Kecerdasan Majemuk.(terjemahan Drs. Alexander Sindoro). Batam Centre: interaksara.

Hasibuan, Malayu S.P. 2006. Manajemen Sumber Daya Manusia, Cetakan Kedelapan. Jakarta: PT. Bumi Aksara 2011. Manajemen Sumber Daya Manusia. Jakarta: PT. Bumi Aksara.

Ibrahim, Malik, Misykat. 2011. . Kecerdasan Emosional Siswa Berbakat Intelektual. Makassar: Aaluddin Press. 
Istiatin dan PW Diyah Aryati Ida. 2016, Modul Manajemen Sumber Daya Manusia Fungsi Operasional, FE-Uniba Surakarta.

Kamus Paedagogik. 1989. .Jakarta: PT. Rajawali, 1989

Mangkuprawira, Sjafri \& Hubeis, Aida Vitayala. 2007. Manajemen Mutu. Sumber Daya Manusia. Bogor: Ghalia Indonesia

Riyanto, Yatim. 2012. Paradigma Baru Pembelajaran. Jakarta : Kencana. Robbins, Stephen, P. 2013. Prinsip-Prinsip Perilaku Organisasi. Jakarta: Erlangga Sarwono, W. Sarlito. 2013. Pengantar Psikologi Umum. Jakarta: Rajawali Pres

Setiawan, Ferry dan Dewi, Kartika. .2014. Pengaruh Kompensasi Dan Lingkungan Kerja Terhadap Kinerja Karyawan pada CV. Berkat Anugrah. Jurnal. Denpasar: Universitas Udayana.

Sunyoto, Danang. 2013. Teori, Kuesioner, dan Analisis Data Smber Daya Manusia (Praktik Penelitian). Yogyakarta: CAPS.

Sugiyono. 2009. Metode Penelitian Administrasi dilengkapi Dengan Metode R\&D. Bandung: Alfabeta.

Ghozali, Imam. 2006. Aplikasi Analisis Multivariated Dengan Program SPSS. Edisi Cetakan IV. Semarang: Badan Penerbit Universitas Diponegoro. . 2009. Ekonometrika. Edisi Cetakan Pertama. Semarang: Badan Penerbit Universitas Diponegoro

Sutrisno, Edi. 2009. Manajemen Sumber Daya Manusia Edisi pertama. Jakarta: Kencana Prenada Media Group.

Untari Sri dan Wahyuati Aniek, 2014. Pengaruh Kompetensi dan Lingkungan Kerja terhadap Kinerja Pegawai. Jurnal Ilmu dan Riset Manajemen, Vol 3, No. 10.

Wirawan. 2009. Evaluasi Kinerja Sumber Daya Manusia. Jakarta: Erlangga.

Zwell, Michael. 2000. Creating a Culture of Competence. New York: John Wiley \& Sons, Inc 